\title{
Financial Management Practices on Financial Performance at Selected Private Insurance Companies, Kigali, Rwanda
}

\section{SEMUCYO Edouard}

\author{
Master of Business Administration in Finance and Accounting of the University of Kigali
}

\begin{abstract}
The general objective of this dissertation was to assess the relationship between financial management practices and the financial performance of private insurance companies in Rwanda. It was guided by the following specific objectives which are to assess the impact of financial management practices on return on investment (ROI) of insurance companies in Rwanda; to examine the impact of financial management practices on return on assets (ROA) of insurance companies in Rwanda and to find out the impact of financial management practices on return on equity (ROE) of insurance companies in Rwanda. The research design used a descriptive causal approach to research that takes cross-sectional data into account and helped the researcher to use the questionnaire and documentary review the primary data collection tool and the secondary data collection analysis, respectively. For the first objective, the study shows that an adjusted R square of $44.8 \%$ of ROI of private insurance companies in Rwanda is attributed to a combination of the four factors independent factors (fixed assets management, accounting information system, financial reporting analysis, and capital structure management) used by private insurance companies in Rwanda. For the second objective, the findings revealed that an adjusted R square of $80.9 \%$ of return on assets of private insurance companies in Rwanda is attributed to a combination of the four factors independent factors (fixed assets management, accounting information system, financial reporting analysis, and capital structure management) used by private insurance companies in Rwanda.For the third objective, the findings revealed that an adjusted $\mathrm{R}$ square of $36.8 \%$ of return on equity (ROE) of private insurance companies in Rwanda is attributed to a combination of the four factors independent factors (fixed assets management, accounting information system, financial reporting analysis, and capital structure management) used by private insurance companies in Rwanda. The study concluded that working capital management, capital structure management, financial reporting analysis and accounting information system, play significant positive effect on financial performance of private insurance companies in Rwanda while fixed asset management have negative effect on the financial performance of private insurance companies in Rwanda. The study is recommending insurance companies' management to implement recommended steps considered as possible ways to ensure improvement of their financial management practices for better financial performance.
\end{abstract}

Key words: Financial management practices, financial performance, insurance companies, Rwanda

\section{Introduction}

Financial management is a variety of management roles of any company, but it is the cornerstone of its success. Inefficient financial management, combined with business uncertainty, often leads to severe problems for businesses (Lakew \& Rao, 2014). Kwame (2017) says that the leading cause of business failures is careless financial management practices. Where the financial decisions are mistaken, whether the owner-manager or hired manager, the company's profitability, and consequently the whole company organization, is affected adversely.

Practices of financial management contribute directly to every company's financial performance. Bhattacharya (2006) stated that a company must manage its financial practices efficiently and prudently to sustain its operations and achieve its goals and goals. Financial management contributes through reliable 
financial management systems such as budgetary controls, ratio analysis, and the CVP analysis to improve business organizations' profitability (Paramasivan \& Subramanian, 2019).

McMahon, et al. (2013) summarize their review of financial management practices in Australia, the United Kingdom, and the United States. In its review, financial management practices include accounting information systems, financing decisions, investment decisions. However, these previous researchers looked into financial management; they did not have other critical areas like working capital management, including accounts receivable, inventory, cash management, and accounts payable management financial practices.

When analyzing the relationship between financial management practices and financial performance, it is essential to note that other factors account for potential influences on the relationship. While the relation between financial administration practices and results is not directly related to these different variables, they must be considered to isolate their impact on performance. These include company size, risk degree, capital intensity, leverage, and industry factors, such as growth, business advertising, market share, R\&D. We will consider such variables as control variables in this analysis. Financial management's primary purpose is to optimize the company's financial capital (McMahon, et al., 2013). In terms of more specific goalsprofitability and liquidity - the study will approach this general objective. Profitability management preserves or raises a company's profit by controlling expenses, price policies, market volume, inventory management, and capital expenditure.

Across nearly all developed and developing nations, insurance is a significant rising part of the financial sector (Selvanayakia, et al., 2016). The robust and well-regulated insurance industry will contribute significantly to economic development and efficient capital allocation through risk transfer and savings mobilization. It can also improve financing efficiency by reducing transaction costs, liquidity creation, and investment economies of scale (Selvanayakia, et al., 2016).

In 1999, Indian governments enabled the insurance industry to privatize, setting up the IRDA to regulate and develop the insurance sector. IRDA issued licenses and opened life insurance market for private companies. After the liberalization in 1999, the insurance sector in India grew, and private actors were allowed to join the life insurance market in India. In terms of premium revenue, new business strategies, and the number of companies, brokers, goods, and riders, the Indian Life insurance industry grew tremendously from 2000 (Demba, 2013). However, the number of insolvent insurers has risen significantly over the past two decades (1995-2015). Rapidly increasing or decreasing interest rates may cause certain insolvencies. In addition, the loss of property like junk bonds, commercial loans, collateral mortgages, immovables, and derivatives has resulted in other losses (Arif \& Showket 2015).

Some have also been affected the churning of unscrupulous sales representatives, insolvencies amongst the reinsurers supporting issued policies, non-compliance with insurance regulations, and malfeasance by insurance officers and managers. Nevertheless, the underlying factors in each of them were the same: insufficient financial management practices, despite the many and disparate apparent causes of the insolvencies (Lasher, 2014). However, this study aims to examine the influence on the performance of insurance companies in Rwanda and, in particular, private companies of different financial management practices.

The insurance industry started in Rwanda in 1975. The insurance industry has gradually grown from this period. In Rwanda, insurers (public and private) and insurance intermediaries (insurance brokers, policymakers, and risk adjusters) have been forming in many insurance firms. For insurance companies, there are currently thirteen (14) companies in the country: two (2) are public health insurers, and twelve (12) are private insurers, of which nine (9) are general or short-term insurers. Simultaneously, Life or Long-Term insurers are three (3).

Since 2013, Rwanda's private insurers have registered a weak output of ROA and ROA, resulting in almost all private insurers being recapitalized. However, until the first quarter of 2018, these companies showed promising signs of improvement; the situation was not critical. Looking at companies, they worked hard to improve the staff's financial management capabilities through career development or capacity-building practices(BNR, 2018). 
In every country's economy, insurance plays a critical role. Insurance is essentially a scheme that extends the losses of some of the many who could face similar losses. This scheme helps protect against financial losses in the case of an unintended event (Ch'ng \& Chang, 2016). The insurance sector in Rwanda is vital as well, and in the past five (5) years, there has been an average increase in gross premium (revenues) of 11 percent. In contrast to other sub-Saharan countries in the region like Kenya with 2.6 percent, however, the insurers penetration rate (Gross Premium Written expressed a proportion of GDP) is still low at 1.7 percent. At the same time, in South Africa, it is still low at 16 percent. This situation implies that there are still opportunities for insurers in Rwanda and that insurers will target them to achieve efficient and effective use of resources in maximizing their revenues and profits. Against that, this study aims to find if that performance is due to the efficient use of financial management practices by taking the case of private insurance companies in Rwanda.

\section{Literature}

The term 'finance management practices' is used to represent the management of funds and how the funds are used to achieve the objectives of the organization and shareholders' value maximization (Sheikh and Osman 2019). According to Jain and Surendra (2015) typical financial management practices in organizations include an accounting information system, fixed assets management, working capital management, financial reporting and analysis, capital structure management etc. These components of financial management practices

Financial management makes a better feeling of financial idea for the organization, more keen concentration on what is deliberately imperious and improved comprehension of a quickly evolving condition (Demba, 2013). In that regard, directing strategic management in manufacturing companies have a pivotal significance as manufacturing companies need to work and compete inside settings of great risk and vulnerability. Nimalathasan and Valeriu (2017).) depict strategic management in autonomous investments as the way toward building up a strategy to direct an organization as it endeavors to attain its vision, mission, objectives and goals and prevent it from straying off course.

Chung and Chuang (2010) classified financial management practice in to the following five specific areas: Capital structure management, working capital management, financial reporting and analysis, capital budgeting and accounting information system. Financial management helps to improve the profitability 3 position of business organizations with the help of strong financial control devices such as budgetary control, ratio analysis and Cost-volume profit (CVP) analysis (Paramasivan \& Subramanian, 2009).

Ofoegbu and Odoemelam (2018) indicate that strategic management conduct in manufacturing companies includes an endeavor to adapt all the more viably to the immense and increasing requests exuding from the external and internal sources (i) giving the improvement of the organization a long-extend bearing; (ii) figuring and implementing a general idea of the organization; (iii) producing, actualizing, and regulating fundamental methodologies and sub-systems; and (iv) using such exceptional "strategic" devices as qualities/shortcomings investigation and opportunity/risk investigation, among others.

The need for implementing the approaches and procedures of strategic management in manufacturing companies can be attributed to the varying states of carrying out business. Abdullahi and Gichinga (2018) note that independent companies are presented to greater risks and vulnerability distinguished with large companies, the conservative business management style of manufacturing companies proprietors or business people for the most part inclined to disregard the strategic management methods, which needed to experience sincere modifications with the developments in the investment condition, as the business individuals and capitalists turned out to be more aware of the difficulties and the opportunities of the settings they are competing in and the feasible competitive advantages their ventures needed to produce, for accomplishing their organizational objectives. In that regard, the potential favorable circumstances of a key viewpoint for manufacturing companies proprietor/directors, summarized by Nimalathasan and Valeriu (2017) as empowering the business person or entrepreneur to assess and express a dream, guaranteeing the checking and examining of the firm and its condition, encouraging the disclosure of new prospects and qualities, controlling the rebuilding of the venture, controlling the procedures of decision making inside the venture, giving a beginning stage to the particular of destinations, going about as a typical dialect for the 
venture's partners were soon acknowledged by manufacturing firms proprietor/administrators, focused to keep up an

Financial management practices in fixed asset management, accounting information systems, working capital management, review of financial statements and management of capital structures are described and delimited to accounting officer practices.

Working capital management refers to the monitoring of the capital available for working and short term finances (Garrison, 1999). It entails the management of the corporate funds so as to increase the interest earned through the maximization of investments and reduction of the interests. This aims to ensure that the organization is able to effectively continue with its operations while having sufficient flow of cash for both short term and future operation expenses. Effective cash management thus ensures the timely provision of cash resources necessary to support the company's operations.

Working capital management was explained by use of cash management, refund and maturity management and current debt management indicators. Good management of debtors is key to having good profits for the company, creditors can be used to manage cash flow deficits and avoid loss of good performance (Fwamba, 2017).

According to Emery, Nimalathasan \& Valeriu (2010) the purpose of cash management is to determine the optimal level of cash needed for operation. They also indicate that the daunting task of cash management is to maintain an appropriate level of cash and marketable securities that reduce the risk of insufficient fund for operation. Thus, a company's competency to synchronize cash inflows with cash outflow, by using cash budgeting and forecasting in formulating a cash management strategy is important. Nimalathasan \& Valeriu (2010), cash flow management is concerned with arranging cash, monitoring account receivable and account payable activities and proper maintaining of inventory. They further posit that an optimum cash flow management affects liquidity and profitability of a firm. Bagchi and Khamrui (2012) asserts that reducing the time cash is tied up in the operating cycle improves a business's profitability and market value furthers the significance of efficient cash management practices in improving business performance

According to Shelfer (2010), Working Capital Management (WCM) refers to working capital and short-term financing decisions. The WCM includes the management of the relationship between short-term assets and liabilities of an organization. The objective of WCM is to ensure that the firm can continue to operate and that it has sufficient cash flow to meet both the maturation of short-term debt and future operating expenses. Management of working capital includes the management of cash, the management of receivables and payables, and inventory management.

For the purpose of this thesis the focus is on movable assets; the acquisition of capital assets can most certainly exert an effect on an organization's competitive advantage over the long term. Capital equipment is characterized by large expenditure and non-recurring expenditure. Purchasing capital equipment usually requires a relatively large capital outlay, which may sometimes amount to millions and which may have particular financial implications. Buying capital equipment can therefore be regarded as an investment which is financed from long-term, rather than from working, capital (Reyhani, 2012).

Capital budgeting decisions are critical to the success of any firm. It is argued that capital budgeting decision is vital to a firm's financial among the most important decisions that owners or managers of a firm must make. Their rationale for that belief is that capital budgeting decision often involves significant capital outlay to acquire fixed assets. Additionally, the acquisition of these assets often comes with long lasting and recurring financial obligation. Furthermore, efficient utilization and control and management of acquired fixed assets are also equally important. Appropriate acquisition process, proper record keeping, periodically evaluating the efficiency of the fixed asset, regular repair and maintenance and proper disposal of fixed assets will enhance the performance of firms (Reyhani, 2012).

Okwo et al., (2014) studied the investment in fixed assets and firm profitability, evidence from the Nigerian Brewery Industry. A cross sectional data was gathered for the analysis from the annual reports of the sampled brewery firms for a period of 1995 to 2009. The four brewery firms that constitute the sample were those quoted on the Nigerian Stock Exchange and their inclusion in the analysis is based on the availability 
of data for the sample period. The brewery firms that constitute the sample are: Nigerian Breweries Plc, Guinness Nigeria Plc and International Breweries Plc, Champion Breweries Plc. The result of the tested hypothesis showed that the level of investment in fixed assets does not strongly and significantly impact on the level of reported profit of breweries in Nigeria.

Fixed assets management has the major role in the profit ratio determination and the evaluation of risk involved (Harvey, 2013). Effective organization of fixed assets is the most important part of the entire corporation and in creating the value of shareholders. The earnings per share is not increased by the minimum weighted average capital cost as the value of the stock of the firm increases due to it. It is important to consider not only the purchase price of capital equipment, but also the total cost of ownership (Okwo, et al., 2014). Capital equipment is usually purchased at irregular intervals. It is used up gradually in the production process, rather than as a part of the end product. Owing to the relatively long lifespan of equipment, it could take several years before it needs to be replaced and, at the time of replacement, old equipment could prove to be technologically obsolete. If the correct purchasing decision is made, capital equipment generates profits for the organization. Incorrect decisions may have disastrous consequences for the enterprise, since it will not be able to sell capital equipment over the short term (Okwo, et al., 2014).

It is essential to consider the purchase price of capital equipment and the total cost of ownership (Hugo, et al., 2016). Capital equipment is generally purchased at irregular intervals. It is gradually used in the production process rather than as part of the final product. Depending on its relatively long lifespan, the equipment could take several years to replace. Old equipment could prove to be technologically obsolete at the time of replacement. The selling rates of equipment and the total ownership costs must also be considered (Hugo, et al., 2016). Capital equipment is generally purchased at irregular intervals. It is gradually used in the production process rather than as part of the final product. Depending on its relatively long lifespan, the equipment could take several years to replace. Old equipment could prove to be technologically obsolete at the time of replacement.

According to Nimalathasan and Valeriu (2017), capital structure management (CSM) means supervising an entity's financial structure. The capital structure of a company refers to the combination of its different funding sources. A mix of debt and equity constitutes the capital of several companies. The costs of the capital structure's components are weighted by the total amount when determining the capital cost of the enterprise. This determines the weighted average capital cost (WACC) of the enterprise. For capital budgeting projects, WACC is used to calculate Net Present Value (NPV). A lower WACC will produce a higher NPV; thus, achieving a lower WACC will always be optimal.

Abdullahi and Gichinga (2018) described capital structure as a precise mix of debt and equity which is normally used to finance the firm's operations. Further added that a firm can select among several alternative sources of capital with different mix of securities. This definition provides its' self for review to firms considering the fact that it emphasizes on specific proportion of debt and equity used for financing organizations.

Shelfer (2010) presented the pie model which gives the relationship between value of a firm and various providers of funds, they also pointed out that the amount of debt a firm chooses relative to equity defines its capital structure. Nimalathasan and Valeriu (2017) pointed out that such a choice is a strategic one which has many implications on the firm, therefore, it should be well managed to ensure that the ultimate interest of the shareholder and other stakeholders of the company are served. The success of any business therefore lies in its management's efforts to identify this optimum capital for smoothness, sustainability, and prosperity in line with her overall goals and objectives. 
Financial reporting entails extracting and presenting data from the accounting system in ways that facilitate analysis (Simson, Sharma \& Aziz, 2011). Financial reports aim to improve budget compliance. They provide a means for internal or external actors to assess government performance. Governments produce a range of reports for internal and external consumption. Typical reports include daily flash reports on cash flows, monthly reports on budget execution, revenue reports, mid-year reports and annual financial statements or fiscal reports. There are internationally recognized minimum requirements for annual fiscal reporting. These reports form the basis for the audit general's review of government performance (Simson, Sharma \& Aziz, 2011).

Wetosi, et al., (2018) noted that financial management should include keeping an accurate record of all financial transactions, linking the budget to the firm's strategic and operational plans. The term accounting is used to describe the process of assembling, analyzing, classifying and recording data that is relevant to transactions and events affecting the government's finances. Assembling involves gathering together purchase orders, invoices, billing statements, notices, receipts, receiving slips, closing documents, bank statements, correspondence, and other documents that support a transaction. These documents must then be analyzed so someone unfamiliar with the transaction can understand who and what was involved; when, where and why the transaction or event took place; and the value to be assigned to it (Wakiriba, et al., 2014).

In the Financial Reporting Analysis (FRA) context, recording and organization of accounting systems will not achieve objectives, except if reports are analyzed by systems and used for management choices. Financial statements typically provide the necessary information for decision-making and planning. To evaluate, plan, and decide by making historical comparisons, we also may use financial reporting information (Butt, et al., 2010).

Financial reports aim to improve budget compliance. They provide a means for internal or external actors to assess government performance. Financial reporting entails extracting and presenting data from the accounting system in ways that facilitate analysis. Governments produce a range of reports for internal and external consumption. Typical reports include daily flash reports on cash flows, monthly reports on budget execution, revenue reports, mid-year reports and annual financial statements or fiscal reports. There are internationally recognized minimum requirements for annual fiscal reporting. These reports form the basis for the audit general's review of government performance (Rebecca, et al., 2011).

Financial reporting is very important in the public sector financial management and also it is considered as the best indicator of accountability (Akhidime \& Ekiomado, 2014). County government financial reporting facilitates provision of information on financial position and operating performance. Korutaro, Nkundabanyanga, and Nalukenge (2017) point out that financial reporting in local authorities needs to be relevant and reliable in order to enable general public to measure performance in terms of efficiency and effectiveness in using public resources. County governments can achieve reliability of financial reporting by ensuring that financial statements are free from material errors and misstatements. Such reports facilitate decision making, transparency and enables discharging accountability.

Ofoegbu and Odoemelam (2018) states that the AIS is generally a computer-based record-keeping system that combines accounting and concepts with the advantages of an information system, analyzes and records business transactions in preparing financial statements, and provides accounting information for users. AIS help analyze the financial statements' accounting information. Romney and Steinbart (2012) defined an accounting information system as a collection of parts and sub systems that are connected with each other and with the surrounding environment and operate as a single overlap relationship between each other and between the system that combines, where each part depends on the other in achieving the goals sought by the comprehensive system of accounting, in order to provide data and information to decision makers. It then means, accounting information systems collect, record, store and handles data to provide information to decision-makers via advanced technology or simple system or in between of the two.

Accounting information systems play crucial and important role, providing information that could help the organization's management perform its duties to the fullest. Many researchers have pointed out that the success or failure of an organization in achieving its objectives depends on the quality of the accounting information systems. The development of accounting information systems has a significant impact on the 
performance and effectiveness of operations in the organization, as the management of the organization needs information that is characterized by consistency and confidence in decision-making. Further, the success of decisions and increasing their effectiveness depends heavily on the success of accounting information systems presented to the decision maker at the right time (Neogy, 2014). In this regard, Rapina (2014) stated that a good and successful system must be characterized by integrity, simplicity, flow of information, multiplicity of elements, in addition to excellence, correlation and correct outputs.

According to Yohanes, et al. (2018), the key financial performance measures are return assets returns (ROA), return on equity (ROE). Still, in insurance companies, it is better to consider Return on Investment (ROI).

Return on Investments (ROI): This ratio is calculated as net profit after tax divided by the total paid-in capital. Thus, it measures the firm's efficiency in utilizing invested capital. In other words, this ratio expresses the company's ability to generate the required return (expected return) based on using and managing the invested resources by the shareholders (Akhidime \& Ekiomado, 2014).

$$
\text { Return on Inestment }=\frac{\text { Net profit after taxes }}{\text { Total paid in capital }}
$$

Return on Assets: Asset Return (ROA) is one of the income ratios. This ratio is most often highlighted in the analysis of the financial statements, as it shows company success for profit-building purposes. In addition, ROA can measure the ability of the company to generate profits for the future in the past. Assets in question are overall corporate properties derived from the capital itself or foreign capital converted into corporate sustainability assets.

According to Brigham and Houston (2001), to calculate the return on asset (ROA), one compares available net profit for common shareholders to total assets.

$$
R O A=\frac{\text { Available net profit for common shareholders }}{\text { Total assets }}
$$

Higher ROA value suggests improved business efficiency due to higher investment rate returns. "This value reflects the return of the client for all assets (or finances) given to it (Yohanes, et al., 2018). Factors affected by the Asset Return are (a). The liquidity ratio is determined by comparing their current assets and their existing liabilities (b) to assess the ability of a company to meet its short-term liabilities. Asset Management Ratio is the "asset management ratio; measures how effectively the company manages its assets. The debt management ratio knows how much the company can meet its long-term (debt) obligations to finance all its operations.

Return on Equity (ROE): In Bahasa (Indonesia), the return on equity (ROE) is often referred to as the profitability of its shares (profitability of its capital) or the return on equity. This profitability ratio, or part of the overall profitability, allocated to shareholders, would encourage investors to buy the shares. The owners are considered to have residual income statements. First, the company's income would be used to pay any debt interest, then transfer the interests and (if any) to common shareholders. ROE is the profitability ratio to assess the company's ability to produce a profit by capital owned by the company. ROE is the profitability ratio. Calculated return on equity (Bagchi \& Khamrui, 2012).

$$
\text { Return on Equity }(\mathrm{ROE})=\frac{\text { Net Income After Tax }}{\text { Total Equity }}
$$

\section{Empirical Review}

Various studies were carried out on organizations' financial reporting activities. For example, 
Rubayah and Radam (2014), studied on the financial Management Efficiency Performance of Insurers and Takaful Operators in Malaysia. The study aimed to assess the financial management efficiency of each insurer/takaful operator in both conventional and takaful industry. We also identify the operating system that is more efficient among the conventional and takaful system which involves 20 firms. The results from the slack-based measure (SBM) - data envelopment analysis (DEA) implied that the average insurers/takaful operators have to improve about $20 \%$ if it were to perform the best financial management practice. Clearly, the inefficiency in both functions of financial management is caused by both the input and output dimensions. This study also revealed that takaful operators exhibit a relatively more efficient financial management in terms of risk management than conventional insurers. However, it cannot be confirmed whether one type of operating system is better than the other system in terms of investment management, as the result is mixed.

Nyongesa (2017), studied on the effect of financial management practices on financial performance of insurance companies in Kenya. The study sought to establish the effect of financial management practices on financial performance of insurance companies in Kenya. The study used both secondary and primary data. Data on gross premium, return on assets and return on equity were obtained from secondary sources while primary data was obtained from responses for the information on the financial management practices used by insurance companies in Kenya. The study adopted correlational research design. The data was analyzed by use of descriptive and inferential statistics. Reliability and validity tests were conducted to determine the internal consistencies of the variables under investigation. Descriptive statistics produced frequencies, trends, means and percentages while inferential statistics produced regression and correlation results which show the relationship among the variables. Analysis of Variance (ANOVA), multiple regression and correlation analysis was carried out to test the hypothesis. Pearson's product-moment correlation coefficient (r) was used to explore relationships between the variables, specifically to assess both the direction and strength. Statistical Package for Social Sciences (SPSS) was used in the analysis of data and results were presented on frequency tables to show how the responses for the various variables and indicators posed to the respondents. The study found that working capital management, capital budgeting techniques, capital structure decisions, claims management policies and corporate governance had positive and statistical significant effect on financial performance of insurance companies in Kenya. It also established that firm characteristics had a moderating effect on the relationship between working capital management, capital budgeting techniques, capital structure decisions, claims management policies, corporate governance and financial performance of insurance companies in Kenya. The study recommends that the management of insurance companies to consider putting in place the recommended steps seen as probable ways of ensuring that their financial management practices are improved for better gross premium, return on assets and return on equity.

Fwamba (2017), studied on the influence of financial management practice on financial performance of sugar manufacturing companies in Kenya. The objective of this study was to establish the influence of financial management practice on financial performance of manufacturing companies using evidence from Kenya's sugar industry. This research adopted a descriptive research design in which a census of all the targeted population of 12 manufacturing companies jointly from sugar manufacturing industry were drawn from a list of 800 manufacturing companies in Kenya, whereby a proportionate random sample of 109 employees were interviewed from all the 12 sugar manufacturing companies in Kenya. Questionnaires were administered as the main tool of data collection whereby 102 questionnaires were collected representing a 93.6\% response rate. Descriptive statistical methods were applied to describe application of strategic financial management practices in the sampled manufacturing companies which were sugar manufacturing companies. Inferential statistical techniques such as Correlation analysis and regression analysis were applied to test the hypotheses of association and differences. Collected data was processed using the Statistical Package for Social Science (SPSS) which was the main computer software that was utilized in data analysis. The strategic capital practices' null hypotheses were rejected implying a significant effect on financial performance. Strategic liquidity practices were significant hence the null hypothesis was rejected. Strategic investing practices had coefficients of estimate which were significant implying that the null hypothesis was rejected. It is therefore recommended that it is important for firms to retain their profits so that they can reinvest and gain higher returns on investments and shareholder equity furthermore 
Organizations need to utilize computers in cash management since they are efficient and effective. This study suggests the need for further research on other economic factors besides financial management practices that influence the financial performance of sugar manufacturing companies and other companies.

Wang'ombe and Kibati (2016), studied on the analysis of financial management practices on effective use of public funds in the county government of Nakuru, Kenya. The study analyzed financial management practices affecting effective use of public funds in the county government of Nakuru. The study specifically examined the implication of records management and internal monitoring on effective use of public funds. The study adopted explanatory research design and it was conducted in the Nakuru County Government's Treasury targeting the 293 staffs involved in the management of finances. A sample of 74 staffs was selected to participate in the study using stratified random sampling technique. Data were then collected using questionnaires administered to the respondents. Data collected were analyzed using descriptive and inferential statistics. The study revealed that records management practices did not have significant effect on utilization of County Government funds. However, internal monitoring and controls significantly influenced the effective use of funds in the County Government. The study concluded that financial practices in the county government were responsible for the funds utilization. as a result, the study recommended that county governments as well as the national treasury should enhance internal monitoring and controls.

Musili and Matanda (2019), studied on the effect of financial reporting on the organizational performance of public corporations under the ministry of tourism in Kenya. Therefore, this study assesses the effect of financial reporting on the organizational performance of public corporations under the Ministry of Tourism in Kenya. The research used descriptive research design. The unit of analysis was nine state corporations under the Ministry of Tourism in Kenya. The unit of observation comprised of 103 staff working the finance and audit departments of public corporation the Ministry of Tourism in Kenya. Semi-structured questionnaires were used to collect primary data. Pre-testing was carried out to examine reliability and validity of data collection instruments. Qualitative data was analyzed through thematic analysis and results were presented in narrative form. Inferential and descriptive statistics were used to analyze the quantitative data through the aid of statistical package called SPSS version 22. Descriptive statistics entailed the use of mean, standard deviation, frequencies and percentages. Inferential statistics focused on Pearson correlation analysis and multivariate regression analysis. The results were presented in tables and figures. The study established that financial reporting has significant effect on the organizational performance of public corporations under the Ministry of Tourism in Kenya. The study recommends that the public corporations under the Ministry of Tourism should control expenditure, regularly review their budget and have a longterm financial forecast to improve on allocation of financial resources.

Kipkirui and Wahome (2018) studied the influence of financial management practices on financial performance of government funded youth group businesses in Kuresoi South Sub - County, Kenya. The objectives of the study were to establish the impact of investment practices, Liquidity practices, financial control practices and financial reporting practices on financial performance of government funded youth group businesses in Kuresoi South sub- County. The target population was 96 top officials from the 32 government funded youth group businesses operating in Kuresoi South sub- County. Descriptive study design was adopted inform of a survey while a census survey was employed. Primary data was used which was collected using structured questionnaires. Data was analyzed using descriptive statistics and inferential statistics methods with the aid of SPSS while research hypotheses were tested at 0.05 significant levels with data presented using distribution tables and inferential statistics tables. The research findings indicate that a statistically significant positive relationship between Investment practices, liquidity practices, financial control, financial reporting practices and financial performance of government funded youth group businesses. Conclusions were made that investments practices, Liquidity practices, financial control and financial reporting practices have a significance influence with financial performance of government funded youth group businesses.

\section{Methodology}

This study used a descriptive approach to research that takes cross-sectional data into account. This design helps the researcher use the interview as the primary data collection tool and the secondary data collection 
analysis. They also used standardized questions to determine the reliability of the articles for an interview guide (Owen 2002).

The population refers to the total of all analytical units. It has one or more characteristics in common as the target population in the world, being or class of human beings, animals, and other things. A population is a number of cases that one would like to conclude (Shuttle, 2009). The target population for this study consisted of 126 of employees of 12 private insurance companies from senior management and finance department

The sample size is defined as all research participants and should be representative of the entire population. The researcher used a sample to study and spread the population, mainly if the whole population cannot be analyzed (Robson 2002). Sampling is the method, technique, or procedure for collecting a subset from a population for the analysis. For this study, the following formula was used:

$$
n=\frac{N}{1+N(e)^{2}}
$$

Where $\mathrm{n}=$ is sample size, $\mathrm{N}=$ is population, $e=$ error tolerance of $5 \%$

$$
n=\frac{126}{1+126(0.05)^{2}}=96
$$

\section{Population and sample size}

\begin{tabular}{|l|l|r|r|}
\hline No & Names of Insurance Companies & Population & Sample size \\
\hline 1 & SONARWA GENERAL INSURANCE & 10 & 8 \\
\hline 2 & SONARWA LIFE ASSURANCE & 10 & 8 \\
\hline 3 & SANLAM ASSURANCES GENERALES & 15 & 11 \\
\hline 4 & SANLAM VIE & 13 & 9 \\
\hline 5 & PRIME INSURANCE & 12 & 9 \\
\hline 6 & PRIME LIFE INSURANCE & 11 & 8 \\
\hline 7 & MUA RWANDA ASSURANCE COMPANY & 10 & 8 \\
\hline 8 & UAP INSURANCE RWANDA & 9 & 7 \\
\hline 9 & RADIANT INSURANCE COMPANY & 10 & 8 \\
\hline 10 & BRITAM INSURANCE RWANDA & 10 & 8 \\
\hline 11 & BK GENERAL INSURANCE COMPANY & 8 & 6 \\
\hline 12 & MAYFAIR INSURANCE RWANDA & 8 & 6 \\
\hline & Total & 126 & 96 \\
\hline
\end{tabular}

For selected respondents, the research tool to be used in this study included questionnaires. In addition, the researcher used the interview schedule to collect data from the staff of the financial departments for financial performance formation.

The study used semi- structured questionnaire. The researcher designed questionnaires for employees of 12 private insurance companies in Rwanda. The questionnaire composed by the five sections, the first part deal with respondents' profile, the second section deals with Working capital management, the third section deals with: Fixed asset management; The fourth section dealt with: Capital structure management, the fifth section dealt with Financial reporting analysis and the last section dealt with accounting information systems. The aim of using this method is to get broad-based views from the respondents. It included close-ended of predetermined answers and a few open-ended questions. The questionnaire also uses a 5-point Likert rating scale to secure the degree of the presence of the variables of interest in the study population.

Interviews were used to gather qualitative data from senior managers in particular. This tool is used because it usually yields the highest level of cooperation and the lowest refusal rate. Also, it provides high-quality responses and incorporates the multi-technical data collection of the interviewer's presence, incorporating 
questioning, cross-examining, and evaluating methods (Polit \& Beck, 2013). The study used interview from five senior management including Chief Executive Officer of Prime Life Limited, Chief Finance Officer and Acting Chief Executive Officer of SANLAM Assurances Générales Plc, Finance manager of MAYFAIR Insurance Rwanda Limited, Chief Internal Auditor of SONARWA General Insurance Limited and Chief Finance Officer of BRITAM.

Data were screened to ensure that responses are legible, understandable, within an acceptable range, and complete. Collected data were coded and entered into the Statistical Package for Social Sciences program for analysis (SPSS version 23.0). The data were analyzed by using both descriptive statistics such as frequencies, percentages, mean and standard deviation, and inferential statistics such as correlation and multiple linear regression analysis was used to analyze the data.

Descriptive statistics: Descriptive statistics such as mean, frequency, and standard deviation was used to describe the level of financial management used by insurance companies in Rwanda in term of working capital management, fixed asset management; capital structure management; financial reporting analysis and accounting information systems and also described the level of financial performance of insurance companies in Rwanda.

\section{Findings, Discussion and Interpretation}

The first objective was to assess the impact of financial management practices on return on investment (ROI) of insurance companies in Rwanda. The results indicate that working capital management, capital structure management, financial reporting analysis and accounting information systems have positive and significant impact on ROI of private insurance companies in Rwanda while fixed asset management have negative and significant impact on ROI of private insurance companies in Rwanda $(\beta 1=0.711$, $\mathrm{p}=0.014<0.05, \mathrm{t}=2.274 ; \beta_{2}=-4.961, \mathrm{p}$-value $=0.009<0.05, \mathrm{t}=-2.791 ; \beta_{3}=0.355, \mathrm{p}$-value $=0.010<0.05, \mathrm{t}=$ $2.373 ; \beta_{4}=0.158, \mathrm{p}$-value $=0.000<0.05, \mathrm{t}=3.033$ and $\beta_{5}=0.096, \mathrm{p}$-value $\left.=0.001<0.05, \mathrm{t}=3.024\right)$, respectively. This shows that 1 per cent increase in working capital management, capital structure management, financial reporting analysis and accounting information systems will lead to $0.711,0.355$, 0.158 and 0.096 percent increase on ROI of private insurance companies in Rwanda while 1 per cent increase in fixed asset management will lead to 4.961 percent decrease on ROI of private insurance companies in Rwanda. Based on the findings above the model two (2) is represented as follows: Financial performance measured by ROI $=8.831+0.711 \mathrm{WCP}-4.961 \mathrm{FAM}+0.355 \mathrm{CSM}+0.158 \mathrm{FRA}+0.096$ AIS. The study shows that an adjusted $\mathrm{R}$ square of $44.8 \%$ of ROI of private insurance companies in Rwanda is attributed to a combination of the four factors independent factors (fixed assets management, accounting information system, financial reporting analysis, and capital structure management) used by private insurance companies in Rwanda.

The second objective was to examine the Impact of financial management practices on return on assets (ROA) of insurance companies in Rwanda. The results indicate that working capital management, capital structure management, financial reporting analysis and accounting information systems have positive and significant impact on ROA of private insurance companies in Rwanda while fixed asset management have negative and significant impact on ROA of private insurance companies in Rwanda $\left(\beta_{1}=0.312, \mathrm{t}=2.386, \mathrm{p}=\right.$ $0.020>0.05 ; \beta_{2}=-0.980, \mathrm{t}=-3.739, \mathrm{p}=0.000<0.05 ; \beta_{3}=0.714, \mathrm{t}=7.098, \mathrm{p}=.000<0.05 ; \beta_{4}=0.614, \mathrm{t}=8.778, \mathrm{p}$ $=0.000<0.05$ and $\left.\beta_{5}=0.322, \mathrm{t}=2.421, \mathrm{p}=0.018<0.05\right)$, respectively. This shows that 1 per cent increase in working capital management, capital structure management, financial reporting analysis and accounting information systems will lead to $0.312,0.714,0.614$ and 0.322 percent increase on ROA of private insurance companies in Rwanda while 1 per cent increase in fixed asset management will lead to 0.980 percent decrease on ROA of private insurance companies in Rwanda. Based on the findings above the model two (2) is represented as follows: Return on assets (ROA) of private insurance in Rwanda $=0.117+0312 \mathrm{WCP}$ 0.980 FAM +0.714 CSM + 0.614 FRA + 0.322 AIS. The study shows that an adjusted R square of $80.9 \%$ of return on assets of private insurance companies in Rwanda is attributed to a combination of the four factors independent factors (fixed assets management, accounting information system, financial reporting analysis, and capital structure management) used by private insurance companies in Rwanda.

The third objective was to find out the impact of financial management practices on return on equity (ROE) of insurance companies in Rwanda. The results indicate that working capital management, financial 
reporting analysis and accounting information systems have positive and significant impact on Return on equity (ROE) of private insurance companies in Rwanda, the results indicate that capital structure management have positive and insignificant impact on Return on equity (ROE) of private insurance companies in Rwanda while fixed asset management have negative and significant impact on Return on equity (ROE) of private insurance companies in Rwanda $\left(\beta_{1}=0.293, t=3.219, p=0.000>0.05 ; \beta_{2}=-0.079\right.$, $\mathrm{t}=-0.334, \mathrm{p}=0.739>0.05 ; \beta_{3}=0.057, \mathrm{t}=0.321, \mathrm{p}=0.749>0.05 ; \beta_{4}=0.415, \mathrm{t}=3.346, \mathrm{p}=0.007<0.05$ and $\left.\beta_{5}=1.402, t=3.027, p=.004<0.05\right)$, respectively. This shows that 1 per cent increase in working capital management, capital structure management, financial reporting analysis and accounting information systems will lead to $0.293 ; 0.057$; 0.415 and 1.402 percent increase on Return on equity (ROE) of private insurance companies in Rwanda while 1 per cent increase in fixed asset management will lead to -0.079 percent decrease on ROE of private insurance companies in Rwanda. Based on the findings above the model two (2) is represented as follows: Return on equity (ROE) of private insurance in Rwanda $=0.463+0.293 \mathrm{WCP}$ $0.079 \mathrm{FAM}+0.057 \mathrm{CSM}+0.415 \mathrm{FRA}+1.402$ AIS

The study shows that an adjusted $\mathrm{R}$ square of $36.8 \%$ of return on equity (ROE) of private insurance companies in Rwanda is attributed to a combination of the four factors independent factors (fixed assets management, accounting information system, financial reporting analysis, and capital structure management) used by private insurance companies in Rwanda.

\section{Conclusion and Recommendation \\ Conclusion}

Based on the findings of this study, the following conclusions can be made that the combination of the five factors independent factors (accounting information systems, fixed asset management, financial reporting analysis, working capital management, and capital structure management) used by private insurance companies in Rwanda contribute significant impact change of $44.8 \%$ in ROA, $80.9 \%$ in ROA and $36.8 \%$ of return on equity (ROE) of private insurance companies in Rwanda. Hence the study rejected all three null hypotheses because p-value is less than 0.05 level of significant. The study concluded that working capital management, capital structure management, financial reporting analysis, and accounting information system play a significant positive effect on the financial performance of private insurance companies in Rwanda. In addition, the study established that working capital has a significant positive, substantial effect on the performance of private insurance companies in Rwanda with specific practices like effective cash and receivables management, keeping track of the stocks and specifying credit limits.

In contrast, fixed asset management hurts the financial performance of private insurance companies in Rwanda. The study concluded that fixed assets management was a critical driver in enhancing the financial performance of private insurance companies in Rwanda. The Private insurance companies in Rwanda have earned income through effective management of fixed assets and cash management.

The study concluded that financial reporting was essential and significant in enhancing the financial performance of private insurance companies in Rwanda. The study concluded that financial reporting practices like Reconciliation of books of accounts, preparing statements of business liabilities, preparing cash flow statements, and tax statements had a significant moderate effect on the performance of private insurance companies in Rwanda.

\section{Recommendations}

Based on the results, findings, and conclusions, the following recommendations have been deciphered. Therefore, it is recommended that the management of insurance companies consider putting in place the recommended steps as possible ways of ensuring that their financial management practices are improved for better financial performance.

For instance, the insurance companies should enhance the process of managing premium arrears as this could be a key to increased gross premium for respective insurance companies. In addition, the insurance companies should also prepare cash-flow forecasts as this could help identify future surpluses and deficits. This will enable the insurance companies to maintain optimal cash balances, which will enable them to meet their financial obligations as they fall due. 
Secondly, insurance companies should evaluate the viability of new projects, including new products launch, in terms of their profitability. The projects or products which promise good returns should be undertaken first. This way, projects or products shall be ranked accordingly, with low returns being undertaken last or not undertaken at all.

Since capital structure management practices positively contribute to financial performance, insurance companies need to retain their profits to reinvest and gain higher returns on investments and improve shareholder equity, as well as to create buffers that should serve in times of financial strain.

Moreover, there is a need for the management to frequently prepare and review their financial reports to identify areas of improvement and take informed decisions on time. Another essential tool to be invested in is accounting information system since necessary to ensure data accuracy.

In addition, since fixed asset management practice negatively contributes to financial performance and considering that fixed assets are critical to the future generation of income and revenues, proper management of fixed assets means that the company has to maintain only desired levels of fixed assets that allow to keep the maintenance costs at the minimum levels, thus improving its profitability.

In addition, the management of the companies needs to get involved in training and skill development, especially in capital budgeting and investments. Training consultants could be used to train the employees, advising the management on the best investment alternatives.

The insurance companies should maintain optimal capital structure and ensure that they fully utilize their debt facility according to their capabilities. Further, it is suggested that insurance companies formulate capital structure decisions that will enhance the company's tax savings. Finally, insurance companies should set up sound claims settlement procedures to help reduce fraudulent activities.

\section{References}

1. Abanis, T., Sunday, A., Burani, A., and Eliabu, B. (2013). Financial management practices in small and medium businessesin selected districts in western Uganda. Research Journal of Finance and Accounting, 4(2), 29-42.

2. Abdullahi, Z.B. and Gichinga, L. (2018). Relationship between financial management practices and financial performance of parastatal in Somalia. A Case of Somalia Civil Aviation and Meteorology Authority. Journal of Novel Research in Economics and Marketing Management, 5(1), 72-84.

3. Akhidime, A.E., \& Ekiomado, E.B. (2014). Adoption and implementation of international financial reporting standards (IFRSs) in Nigeria: Enduring challenges and implications. International Journal of Development and Sustainability, 3(11), 2090-2100.

4. Arif, A., \&Showket, A. (2015). Relationship between financial risk and financial performance: an insight of Indian insurance industry. International Journal of Science and Research, 4(11), 14241433.

5. Bagchi, B., and Khamrui, B. (2012). Relationship between Working Capital Management and Profitability, A study of Selected FMGG Companies in India [On -Line]. Business and Economic Journal

6. BNR. (2018). Annual Report. Claims Reports from the Faculty of Claims of the Chartered Insurance Institute. Kigali, Rwanda: BNR

7. Borthick, A. F \& Clark, R. L. (2018). Making accounting information systems work: An empirical investigation of the creative thinking paradigm. Journal of Information Systems, 4(3), 48-62.

8. Butt, B., Hunjra, A., and Rehman, K. (2010). Financial Management Practices and Their Impact on Financial Management Challenges in Small and MediumSized Enterprises: A Strategic Management

9. Ch'ng,A and Chang, D. M.(2016). Small Enterprise Financial Management: Theory and Practice, Harcourt Brace, Sydney.

10. Demba, G. A. (2013). The Effect of Financial Management on KMTC Financial Performance. Retrieved from http://erepository.uonbi.ac.ke Retrieved on26th, July 2020

11. Fwamba, R.S.(2017).Influence of financial management practice on financial performance of sugar manufacturing companies in Kenya. The Engineering Economist, 64(4), 300-11. 
12. Hugo, W.M.L., Badenhorst-Weiss, J.A. \& Van Biljon, E.H.B. (2016). Purchasing \& supply management. Pretoria: Van Schaik.

13. Jain, K.P. and Surendra, J.S. (2015). public sector enterprises' Financial management practices: capital budgeting decisions. Management Research Advances Journal, 2(1), 32-46.

14. Kipkirui,R.and Wahome, A.(2018). Influence of financial management practices on financial performance of government funded youth group businesses in Kuresoi South Sub - County, Kenya. International Journal of Economics, Commerce and Management United Kingdom, 6(6),444-481

15. Korutaro, S., Nkundabanyanga, B. A. and Nalukenge, I. (2017). The Relationship Between financial management practices and loan performance of Microfinance Institutions. Social Economic Journal, 44(1), 114-131.

16. Kwame,B., (2017). Financial management practices of small firms in Ghana: An Empirical Study. Journal of Risk and Insurance, 74(2), 377-399.

17. Lakew, D. M. \& Rao, P. D. (2014). Effect of financial management practices and characteristics on profitability: A study on Business Enterprises in Jimma Town, Ethiopia. Journal of Research in Commerce \&Management, 65-70.

18. Lasher, W. (2014). Practical Financial Management, (2nd Edition). Thomson South-Western.

19. McMahon, R. G. P., Holmes, S., Hutchinson, P. J., Forsaith, D. M, (2013). Financial Management for Small Business, 2nd edition, CCH Australia IRDA, Journal various issues, 2010 to 2015.

20. Muli, B.M. and Rotich, G. (2016). The relationship between financial management practices and County Governments' budget implementation in Machakos County. The Strategic Journal of Business and Strategic Change, 3(40), 756-771

21. Musili,F.M. and Matanda, W.J.(2019). Effect of financial reporting on the organizational performance of public corporations under the ministry of tourism in Kenya. International Journal of Business Management and Finance,3(2),83-125.

22. Neogy, T. (2014). Evaluation of Efficiency of Accounting Information Systems: A Study on Mobile Telecommunication Companies in Bangladesh. Global Disclosure of Economics and Business, Vol.3, No 1, 40-50

23. Nguyen, K.M.(2014). Financial management and profitability of small and medium enterprises,' DBA thesis, Southern Cross University, Lismore, NSW

24. Nimalathasan, B., \& Valeriu B., (2017). Capital Structure and Its Impact on Profitability: A Study of Listed Manufacturing Companies in Sri Lanka. Revista Tinerilor Economisti/The Young Economists Journal, 13(5), 55- 61.

25. Nyongesa, M.N.(2017).Effect of financial management practices on financial performance of insurance companies in Kenya. International Journal of Business and Management, 5(11), 140-162

26. Paramasivan, C. \& Subramanian, T. (2019). Financial management (1st). New Age International (P) Ltd., Publishers.

27. Pike,R.H.(2016). Sophisticated capital budgeting systems and their association with corporate performance; Managerial and Decision Economics, 5(2), 91-97.

28. Polit, G. \& Beck, H, (2013). Sampling methods, London, Pearsons, Prentice Hall

29. Ofoegbu, G.N. and Odoemelam, N. (2018). Effect of financial reporting on performance of firms in Nigeria. Financial Management Journal, 5(6), 1-18.

30. Ojeka, A.S. Mukoro, O.D. and Kanu, C. (2015). Effect of Financial Reporting on Performance of Manufacturing Firms in Nigeria. Social Science Journal, 6(6), 332.

31. Okwo, M., Okelue, U., \& Nweze, A. (2014). Investment in fixed assets and firm profitability: Evidence from the Nigerian breweries industry. European Journal of Business and Management, 4 (20), 10-17.

32. Rapina (2014). Factors Influencing the Quality of Accounting Information System and Its Implications on the Quality of Accounting Information. Research Journal of Finance and Accounting, 5(2), 148-154.

33. Reyhani, A. G. (2012). The investigation of effect of assets structure on performance of accepted companies of Tehran Stock Exchange (TSE). Journal of Basic and Applied Scientific Research, 2(2), 1086-1090.

34. Romney and Steinbart (2012). Computerized Accounting Information Systems and Perceived Security Threats in Developing Economies: The Nigerian Case. Universal Journal of Accounting 
and Finance, Vol. 1(1), 9-18. Rosenfield, P. (2015). The Focus of Attention in Financial Reporting. ABACUS, 41 (1), 1-20.

35. Rubayah,Y. and Radam, A.(2014).Financial Management Efficiency Performance of Insurers and Takaful Operators in Malaysia. Jurnal Pengurusan,40(2),25 - 40

36. Sarapaivanich, N. (2013). The use of financial information in financial decisions of SMEs in Thailand. Journal of the Royal Statistical Society,7 (48), 170-182.

37. Selvanayakia, S., Sivakumara, S.D. and Rohinia, A. (2016). The effect of Financial Management Practices in Modern Rice Milling Firms' Profitability in Kangayam Cluster, Tamil Nadu. Economics and Agriculture Research Review, 21(2), 97-106.

38. Shelfer, V. (2010). Working capital management and financing decision: Synergetic effect on corporate profitability. International Journal of Management, Economics and Social Sciences, 2(4), $233-251$.

39. Simson, R., Sharma, N., \& Aziz, I. (2011). A guide to public financial management literature for practitioners in developing countries. London: Overseas Development Institute.

40. Wakiriba, J.W., Ngahu, S., \& Wagoki, J. (2014). Effects of financial controls on financial management in Kenya ${ }^{e e}$ s public sector: A case of National Government departments in Mirangine Sub-County, Nyandarua County. IOSR Journal of Business and Management, 16(10), 105-115

41. Wang'ombe, J. M.\& Kibati, P.(2016). Analysis of financial management practices on effective use of public funds in the county government of Nakuru, Kenya. International Journal of Economics, Commerce and Management United Kingdom,4(4), 1197- 1223.

42. Yohanes, D., Debela, K.L. and Shibru, W. (2018). The impact of Financial Management Practices on Profitability of Small-Scale Enterprise: Case Study Hawassa City Administration, Ethiopia. IOSR Journal of Business and Management, 20(6), 39-45. 